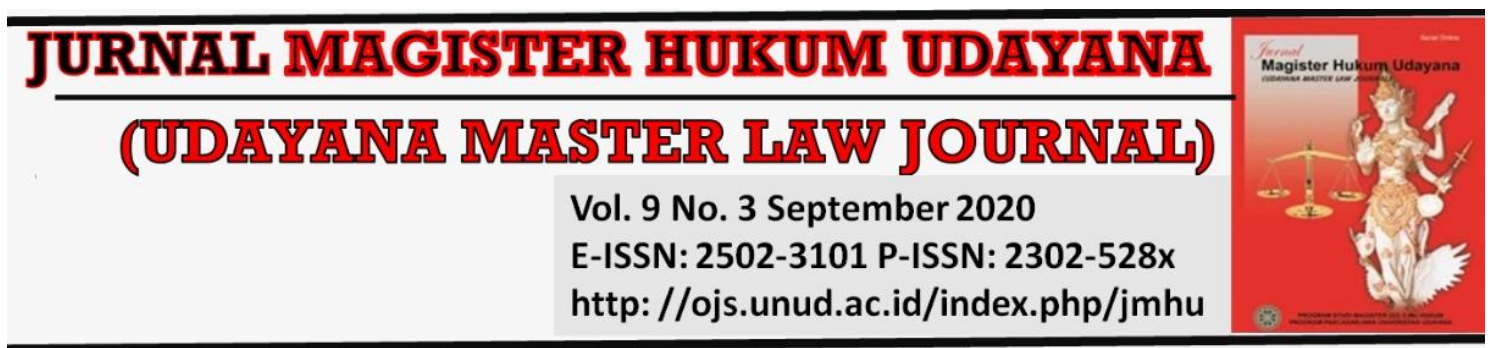

\title{
The Role of the Prosecutor in Executing the Payment of Replacement Money
}

\author{
I Gede Artha1, Ni Nengah Adiyaryani² \\ 1Faculty of Law, Udayana University, E-mail: gede_artha@unud.ac.id / \\ gedeartha_fhunud@yahoo.com \\ 2Faculty of Law, Udayana University, E-mail: nengah_adiyaryani@unud.ac.id / \\ adiyaryani@yahoo.com
}

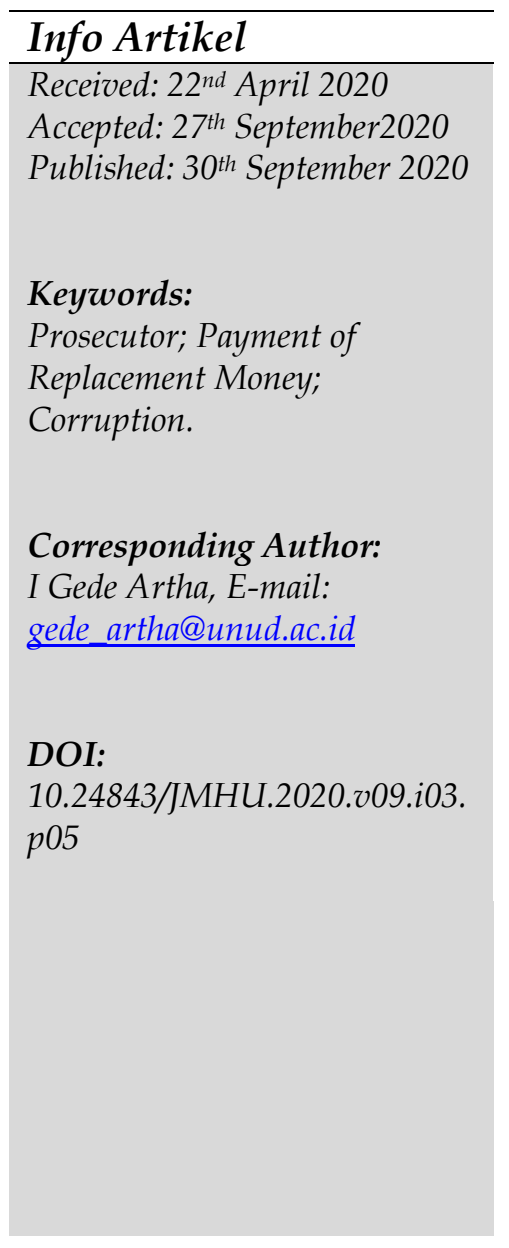

\begin{abstract}
This research is about the role of the Prosecutor as an executor in executing the assets of the convicts of corruption, to recover the State financial losses from corruption. Besides that, this research aims to know about the returning of State financial losses through the payment of replacement money. Corruption is an extraordinary crime, veiled and endanger national stability and security and inhibiting Indonesian economic development. This research is a normative legal research with primary, secondary and tertiary legal material supported by data. This research is using statutory, case, and comparative approaches. The legal basis used in this research are Law No. 31 of 1999 in conjunction with Law No. 20 of 2001, Law No. 16 of 2004 and Law No. 8 of 1981 (Indonesian Criminal Procedural Code). The corruption has become systematic and the scope enters into all aspect of life, start with the lower level with State Officers and law enforcers becomes the dominant actors. In imposing the sanction, The Judges are not only charge imprisonment but also charge additional fines and/or penalties to returning the State financial losses and ask the convicts of corruption to pay the replacement money to the State. The problem arises in this research related to the execution of the verdict about returning State financial losses which are the assets of the convicted person is already in the third party hands or have been depleted, dual population administration, the length of the judicial process, the convicted person prefers to take the subsidiary criminal charge and the hollow of norm regarding technical execution for the Prosecutors so that the execution cannot be carried out.
\end{abstract}

\section{Introduction}

As a logical consequence that Indonesia is based on the law (rechtstaat), therefore the law must be upheld. One of the areas of law that becomes the priority of reform government is to prevent and eradicate corruption. Corruption is very detrimental to the finances of the state and society so it can inhibit national development., therefore all kinds of actions that are detrimental to the State finances need to be eliminated completely by maximizing the power and forced of the existing regulation by law 
enforcement. ${ }^{1}$ For Indonesia, the phenomenon of corruption has increased and spread continually and penetrate almost all sectors of life. Corruption is mainly caused by 3 (three) things, Firstly, corruption by greed, secondly, corruption by need and thirdly, corruption by chance. ${ }^{2}$ The modus operandi of corruption is complicated and difficult to disclose. Various qualifications of corruption have been classified as extraordinary crimes, transnational crimes, hidden crimes, white-collar crimes, crimes against humanity.

Handling a corruption must be in extraordinary ways (extraordinary power). Corruption has penetrated various sectors of life, end even the dominant actors are carried out by the executive, legislative and judicative, as well as involving ministries till the lowest government structures such as Village apparatus or Village officials.

The impact of corruption has been felt and stated as very detrimental to the finance of the country and inhibiting national development, so it must be eradicated in order to create justice and prosperity in a society based on Pancasila and the 1945 Constitution of the Republic of Indonesia. Corruption in Indonesia develops systemically. For many people, corruption is no longer a violation of the law but it becomes a bad practice. Corruption is a real threat to a nation because it causes financial and economic losses to the country and inhibits national development. ${ }^{3}$

The duties and authority of the Prosecutor are quite broad, because they represent the state in restoring public rights when violations of law occur. This research only examines the role of the Prosecutor in executing the convicts of the corruption regarding the state losses so that the financial losses/state assets can be returned by the corruptors through the payment of replacement money.

In the provisions of the Indonesian Criminal Procedure Code, Law No. 16 of 2004 concerning the Indonesian Attorney General, also in Law No. 31 of 1999 in conjunction with Law No. 20 of 2001 concerning Eradication of Corruption there is no provision of legal norms regulating technical actions for prosecutors that can be carried out, when executing assets or property belonging to a corruption convict has been exhausted or belongs to someone else.

In accordance with the results of the research conducted by Transparency International and Political and Economic Risk Consultancy based in Hong Kong, Indonesia always has a vulnerable position in the concern of corruption. It must be recognized that corruption in Indonesia is systemic and endemic so that its not only harm the country's

\footnotetext{
${ }^{1}$ Lukas, A. P. (2010). Efektivitas Pidana Pembayaran Uang Pengganti Dalam Tindak Pidana Korupsi (Studi Putusan Tindak Pidana Korupsi di Pengadilan Negeri Purwokerto). Jurnal Dinamika Hukum, 10(2), 81-92. DOI: http://dx.doi.org/10.20884/1.jdh.2010.10.2.142.

2 Prasetyo, D. R. (2016). Penyitaan Dan Perampasan Aset Hasil Korupsi Sebagai Upaya Pemiskinan Koruptor. DiH: Jurnal Ilmu Hukum, 12(24), 149-163. DOI: https://doi.org/10.30996/dih.v12i24.2243.

${ }^{3}$ Sinulingga, E. E. (2017). Pengembalian Aset Hasil Tindak Pidana Korupsi Melalui Mekanisme Gugatan Perdata. Lex Administratum, 5(4).
} 
finances but also violates the social and economic rights of the society. 4 This structural crime is made corruption as part of organized crime. ${ }^{5}$

The increasing of Science and Technology the variety of a crime is also growing. Money laundering practices are often carried out on money obtained from corruption. Money laundering is an act that aims to change an acquisition of funds illegally so that it appears to be obtained from funds or legal capital. ${ }^{6}$ Money laundering is then used as a shield for the money from corruption.

The efforts to eradicate money laundering in its development not only eradicate the results of its original crime such as narcotics but also corruption. The practice of money laundering with corruption as a crime of origin is very popular in Indonesia. Corruption has brought the county into decline in various aspects, including low economic growth, rising unemployment, poverty and crime. Indonesian Government has made an effort in combating corruption, corruption and money laundering becomes the priority to fight. Any form of criminal acts is detrimental to society and anti-social.

Law enforcers involved in eradicating corruption are investigators, prosecutors and judges. Judges are the final determinant in combating corruption. However, the Judge cannot act actively outside the context of the case that proceeds to the court by the Prosecutor. While those who are active in conducting investigations and prosecutions are the Prosecutors. Therefore, it is no exaggeration to say that the Prosecutors is one of the determinants of success in combating corruption. Likewise, if the case fails, the Prosecutors will be deemed failed resolving this problem.

Law is the factors that cannot be ignored to achieve law enforcement because if ignored will lead into the failure in achieving the expected law enforcement. ${ }^{7}$ Therefore, the existence of The Prosecutor's Office as a law enforcement agency has a central position and strategic role in a rule of law because the Prosecutor's Office becomes a filter between the investigation process and the examination process at the trial so that its presence in the community must be able to carry out the law enforcement duties. In addition to its position as a government institution that carries out State power, especially in the field of prosecution in the general court, it also established the duties and authority of The Prosecutor's Office in the field of civil and State administration, Prosecutors with special powers can act both inside and outside the court for and on behalf of the State Government, public order and other duties and authorities based on

\footnotetext{
${ }^{4}$ Jaya, N. S. P. (2008). Beberapa Pemikiran Ke Arah Pengembangan Hukum Pidana. Citra Aditya Bakti., h.57.

${ }^{5}$ Rewah, C. D. (2019). Pengembalian Kerugian Negara Akibat Tindak Pidana Korupsi Berdasarkan Undang-Undang Nomor 20 Tahun 2001. Lex Crimen, 8(7).

${ }^{6}$ Siahaan, N. H. T. (2005). Pencucian Uang Dan Kejahatan Perbankan: (Mengurai UU No. 15 Tahun 2002 Dengan Perubahan UU No. 25 Tahun 2003 Tentang Tindak Pidana Pencucian Uang). Pustaka Sinar Harapan., h. 7.

7 Soekanto, S. (1983). Faktor-Faktor Yang Mempengaruhi Penegakan Hukum. Rajawali., h.5.
} 
the Law. ${ }^{8}$ As law enforcer, prosecutors should also provide sanctions to perpetrators of crimes that cause deterrent effects. The punishment made by Prosecutors should not only be in the form of imprisonment but also sanction that makes deterrence, shame and fear. ${ }^{9}$

In the criminal field, as stated in Law No. 16 of 2004 concerning the Attorney General of The Republic of Indonesia, in Article 30 paragraph (1) point d, the prosecutors have the duty and authority to investigating certain criminal offenses based on the Law. The authority in the provision as regulated for example in Law No. 31 of 1999 concerning Eradication of Corruption as amended by Law No. 20 of 2001 in conjunction with Law No. 30 of 2002 concerning the Corruption Eradicating Commission, and Law No. 8 of 2010 concerning Prevention and Eradication of Money Laundering.

After the occurrence of corruption and which is not infrequently followed by money laundering then a problem arises related to returning the losses suffered by the state from corruption and money laundering. One of the ways to recover the losses is to impose additional penalties in the form of payment of replacement money. In this way, it will produce results in the form of income into the state treasury from the payment of replacement money.

Research on the role of prosecutors in executing the payment of replacement money from convicted corruption has a different study from the previous research which also examined the role of prosecutors in executing replacement money from corruption. There are some previous studies related to the role of prosecutors in execution, which are: by Ade Paul Lukas in 2010 entitled The Effectiveness of Criminal Payment of Replacement Money in Corruption (Study of Corruption Verdict in Purwokerto District Court) that focusing the effectiveness of the payment of replacement money in corruption in Purwokerto District Court and factors constraining the effectiveness of the implementation/execution of the payment of replacement money in corruption in Purwokerto District Attorney.10 Secondly, Aliyth Prakarsa and Rena Yulia entitled Asset Recovery Model as an Alternative to Restoring State Losses in Corruption Cases, the focus of this paper is to examine the application of asset recovery models as alternative law enforcement that can be done in a corruption case and examine the procedure and mechanism that is possible to

\footnotetext{
8 Syarifuddin, M. S. A. (2019). Wewenang Jaksa Pengacara Negara Dalam Pengembalian Uang Pengganti Perkara Tindak Pidana Korupsi. Simbur Cahaya,25(2), 207-223. DOI: http://dx.doi.org/10.28946/sc.v25i2.331.

9 Mahmud, A. (2017). Dinamika Pembayaran Uang Pengganti Dalam Tindak Pidana Korupsi. Jurnal Hukum Mimbar Justitia, 3(2), 137-156. DOI: https://doi.org/10.35194/ihmi.v3i2.216.

${ }^{10}$ Lukas, A. P. Ibid.
} 
do in the current criminal justice system and examine the application of the model of asset recovery in recovering state losses. ${ }^{11}$

This research is to know the legal basis that correlated and harmonious that related to criminal regulations related to the procedure of Prosecutors in executing the payment of replacement money from convicted of corruption and why they choose subsidiary criminal charges rather than paying replacement money to the state.

The problem that arises in this paper are, whether there is a correlated and harmonious legal basis in criminal legislation related to the procedures for Prosecutors in executing payment of replacement money from convicted corruption and why they choose subsidiary criminal charge rather than paying a replacement money to the State.

\section{Research Method}

This research is empirical legal research preceded by a gap between das solen and das sein. This is descriptive legal research using data collection techniques and field research at Bali High Prosecutor's Office using interview techniques. The sample is determined by a non-probability sampling technique after the data is collected then analyzed using a descriptive qualitative technique.

\section{Result an Discussion}

\subsection{The Law Number 31 of 1999 Concerning Eradication of Corruption in Conjunction With Law Number 20 of 2001 Concerning Amendments to Law Number 31 of 1999}

As the legal basis for the eradication of corruption, Law Number 31 of 1999 has experienced many improvements. The Government's goal to amend that law is an effort to encourage authorized institutions in combating corruption, so that they can reach various modus operandi of corruption and minimize legal loopholes which can be used as an excuse for corruption perpetrators to break away from the bondage of the law. 12

Several important things are reforms in the current Corruption Act, which are:

1. The explicit formulation of corruption as a formal offense, so that any return of state financial losses does not eliminate criminal prosecution of the defendant.

2. The application of the concept against the material law (materiele wederrechtelijheid) in its function positively.

3. The existence of regulations on corporations as the legal subjects besides individuals.

4. There are additional penalties related to the replacement money.

11 Prakarsa, A., \& Yulia, R. (2017). Model Pengembalian Aset (Asset Recovery) Sebagai Alternatif Memulihkan Kerugian Negara Dalam Perkara Tindak Pidana Korupsi. Jurnal Hukum PRIORIS, 6(1).

12 Chaerudin, S. A. D., \& Fadillah, S. (2008). Strategi Pencegahan \& Penegakan Hukum Tindak Pidana Korupsi, Bandung: PT. Reflika Aditama. h. 5. 
5. There is a regulation regarding the validity area or criminal jurisdiction that can be imposed beyond the borders of Indonesia.

6. There is a regulation regarding a "balanced burden of proof" reversal of the burden of proof in Article 37 Law Number 31 of 1999.

7. There is a regulation concerning criminal threats with a special minimum system besides the maximum threats.

8. The introduction of criminal threats is an element of weighting.

9. There is an arrangement regarding joint investigation teams in corruption cases which are difficult to verify under the coordination of the Supreme Prosecutor.

10. There is a regulation concerning the investigation into broader bank secrets begin by freezing of the defendant's account which can be followed by confiscation.

11. The existence of arrangements regarding community participation as social control that is reinforced and expanded, so that legal protection for reporting witnesses is more optimal and effective.

12. There is a regulation mandating lawmaker to a form of independent Corruption Eradication Commission.

13. There is an acknowledgment that explicitly mentions corruption as an "extraordinary crime", means a crime whose eradication must be carried out in extraordinary ways.

14. Formulation of gratuity as a form of corruption.

15. Restricting the burden of proof reversal (omkering van de bewijslast) reversal system.

16. Expansion of the source of evidence that can be obtained from the information that is spoken, sent, received or stored electronically.

\subsection{Some Legal Actions That Can be Performed by The Prosecutors in Their Function as the Executor to Recover State Financial Losses Through Replacement Money}

In addition to representing and providing protection for individual victims, Prosecutors must also represent the State, when the State becomes a victim of the crime. Several acts of citizen can harm the country, such as corruption, tax crime, etc. ${ }^{13}$ The payment of replacement money in Indonesia is a new thing, that's why there are regulated in a few regulations. ${ }^{14}$

The theory of restitution of State finances is a legal theory that explains the system of repayment of State finances based on the principles of social justice that provide the ability, duties and responsibilities to the State institutions and legal institutions to provide protection and opportunities for individuals in society to achieve prosperity. This theory is based on the basic principle given to the State which is the right of the State. In the right of the State contained State obligations which are individual rights of

\footnotetext{
13 Prakarsa, A., \& Yulia, R. Ibid.

14 Kenap, D. (2017). Penyelesaian Uang Pengganti Oleh Ahli Waris Dalam Tindak Pidana Korupsi Berdasarkan Undang-Undang Nomor 31 Tahun 1999 Tentang Pemberantasan Tindak Pidana Korupsi Sebagaimana Telah Diubah Dalam Undang-Undang Nomor 20 Tahun 2001 Tentang Tindak Pidana Korupsi. Lex Administratum, 5(4).
} 
society, so that the principle is equal and congruent with the principle of giving the people their rights. ${ }^{15}$

The form of anticipated legal action carried out by The Prosecutor as investigators and executors to recover State financial losses from defendants. Corruption convicted which are:

1. Accuse the defendant in a careful, clear and complete manner in the form of layered indictments or forms of combination or subsidiary charges.

2. Prosecuting the defendant through a requisitor before the trial with more than one principal or double conviction, accompanied by additional types of criminal charges such as the provision of Article 20 point $b$ number 2 of the Indonesian Criminal Code in conjunction to Article 18 paragraph (1) point a (seizure of/confiscation of goods) and point $b$ (payment of replacement money) law No. 31 of 1999 in conjunction with Law No. 20 of 2001 concerning eradication of corruption.

3. Prosecutors take legal action by submitting an appeal to the High Court and appeal to the Supreme Court if they are not satisfied with the verdict of the District Court and/or the verdict of the High Court.

4. Attorney General c/q Prosecutors as law enforcers, Government, Public Legal Entities that represent the public interest can submit applications for cassation to the Supreme Court as stipulated in Article 259 paragraph (1) of the Indonesian Criminal Procedural Code.

5. Prosecutors as investigators of corruption as early as possible carry out confiscation or seizure of assets of the corruption in order to avoid the loss of evidence.

6. The Prosecutor immediately detains the case after the case has been delegated by the investigator, and does not provide a request for the suspension of detention of the defendant.

7. Functioning, optimizing and pioneering cooperation with other law enforcement agencies and related institutions in calculating and tracking the financial losses incurred by corruptors. As coordinated with KPK, BPK, PPATK whose audit are stated in their demands in court, as a realization of Indonesian Presidential Decree No. 82 of 2013 concerning Procedures for the Implementation of the Authority of PPATK.

8. The Prosecutor can optimize his function as a State Attorney to sue a civil suit of assets held by a corruption convict or their family in terms of recovering State financial losses.

However, the Prosecutor still has to prove through the indictment that it continues to have an impact on the demand that the defendant has committed an act like their initial indictment.

${ }^{15}$ Syaifulloh, A. (2019). Peran Kejaksaan Dalam Pengembalian Kerugian Keuangan Negara Pada Perkara Tindak Pidana Korupsi. Indonesian Journal of Criminal Law, 1(1), 47-64. DOI: https://doi.org/10.31960/ijocl.v1i1.147. 


\subsection{Legal Action of Prosecutor by Confiscating Certain Items}

\subsubsection{Definition of Confiscation of Goods/Confiscation}

The Prosecutor is deemed necessary to pay attention to one of the additional criminal types stipulated in Article 10 of the Indonesian Criminal Code point 2 in the form of "seizure of certain items". The word "deprivation" should not be interpreted narrowly, which has often been interpreted as being taken over and controlled for the State.

Deprivation in relation to additional types of criminal conduct that still exist today and continues to be recognized and practiced in the world of justice. Expropriation is defined as an act in the sense of action for Prosecutors as investigators of specific criminal offenses, one of which is corruption has the legal authority to take legal action in the form of confiscation of the goods belonging to the defendant or items that are suspected either directly or indirectly related to corruption.

Appropriation of assets resulting from corruption is a very important legal remedy in order to return corruption asset to the State, to be used for the interest of national development and the State is still faced with various obstacles in its implementation. ${ }^{16}$

Prosecutors as investigators and Prosecutors in corruption based on the Indonesian Criminal Procedural Code and Law No. 16 of 2004 has attributive authority given the law in carrying out forced measures such as confiscation.

In the context of general theory, confiscation of certain goods is as follows: first, confiscation in the sense of confiscation of goods is used to carry out criminal acts or instumentum sceleris. ${ }^{17}$ Second, confiscation in the sense of confiscation of an object related to a criminal act or objectum sceleris. Third, confiscation in the sense of confiscation of the result of a criminal act or fructum against sceleris. For Indonesia, the three types of seizure need to be interpreted as an act of confiscation of the goods belonging to the defendant in the interest of the State or the wider community.

So that the Prosecutor as prosecutor and as the investigator in the criminal case in his charge besides orienting the additional types of crime as regulated in Article 10 of The Indonesian Criminal Code point $\mathrm{b}$ number 2 also correlates with the possibility for the prosecutor to carry out the mandate governing the provisions of Article 18 paragraph (1) point a stated in the forefront of being able to seize tangible or intangible goods, movable or immovable property used or as a result of corruption, in the sense of grammatical interpretation of the word confiscation is equated with confiscation (in the broad sense).

Then the attributive authority of the Prosecutor and as an investigator in corruption for the Prosecutor's institution or the Prosecutor in carrying out forced measures in the form of confiscation of the proceeds of crimes from the corruptors is appropriate, reasonable and legal for the benefit of the welfare of the wider community in accordance with the essence and meaning of the theory of function, law enforcement is useful for the wider community, especially the financial losses of the State controlled

${ }^{16}$ Deli, R. R. (2016). Implementasi Perampasan Aset Hasil Tindak Pidana Korupsi Menurut Undang-Undang. Lex Administratum, 4(4).

17 Hiariej. E. O. S. (2014) Prinsip-Prinsip Hukum Pidana, Jakarta, Cahaya Atma Pustaka. h. 403. 
by the accused or convicted of corruption can return the lap of the state or the society for the benefit of the socio-economic development of the nation.

\subsubsection{The Purposes and Objectives of Confiscation of Goods/Confiscation of Assets}

Legal action in the form of confiscation of certain items or confiscation by the prosecutor as the public prosecutor in corruption intends to take over the property of the defendant in the possession of the investigator in the interim period. Temporary in the sense of the need for proof at the court. After the verification process is completed, if the goods are no longer in use or there is no connection with the case in which the items occur, the items returned to the owner or to the must entitled party. The dangerous goods are destroyed by the State.

According to Article 38 paragraph (1) of the Indonesian Criminal Procedural Code, the confiscation by an investigator is required by permission of the Head of the District Court. However, in corruption case as regulated in Article 47 paragraph (1) of Law No. 30 of 2002 concerning Corruption Eradication Commission, investigators can conduct a confiscation without the permission of the Head of District Court regarding their investigative duties. The provisions on the regulation of irregularities and their special nature are intended to make the process of handling corruption cases can proceed quickly, efficiently and cut the long bureaucratization so that they do not hamper the process of further cases.

Impoverishment of corruptors as additional crimes can be carried out against corruptors and TPPU as an optimization of returning State financial losses and as an anticipation for other corruptors of TPPU by developing and based on the theory of "dignified justice". The implementation in the main criminal case if the assets of corruptors who have been confiscated have fulfilled the State loss and returned 100\%, then the additional criminal concept in the form of "impoverishment of corruptors" will still be carried out by confiscating/seizing the assets of the convicted in equal amount to the State loss. However, if the convicted cannot recover the State financial losses, the last alternative is a criminal offense (prison) that the duration will be the same as the main criminal punishment and must not exceed the main criminal punishment that has been inkracht. ${ }^{18}$

The objective of confiscation are:

1. For the used as evidence in the verification process at the trial

2. In order to support other types of evidence to avoid the essence of the principle of unus testis mullus testis

3. To prevent taking over the evidences by other parties

4. To prevent money laundering of that asset, that make the prosecutors difficult to trace

5. To prevent other parties, remove or destroying the evidences ${ }^{19}$

6. To make the Prosecutor easily execute the goods after the case solve by Verdict, so the State assets are saved ${ }^{20}$

\footnotetext{
18 Prasetyo, D. R. Ibid.

${ }^{19}$ Surachmin \& Cahaya, S. (2011). Strategi \& Teknik Korupsi. Jakarta: Sinar Grafika. h. 76.
} 
7. If the Prosecutor successfully executing the goods belonging from the convicted, the State has no loss, the Verdict can be carried out in accordance, so that the recovery of State financial losses can be saved

8. The existence of Article 18 paragraph (1) point $a, b, c$ and d of Law Number 31 of 1999 concerning Corruption related to additional criminal offenses in the future is improved, especially the payment of replacement money from corruption.

\subsection{Legal Actions Done by The Prosecutors in Dealing with Arrears in Payment of Replacement Money from The Convicts of Corruption}

The actions of State Attorney in carrying out their duties and functions are greatly influenced by substance, legal procedures, infrastructure and coordination/cooperation carried out internally and externally in an effort to recover the financial losses of the state or the payment of replacement money due to corruption. ${ }^{21}$

The payment of replacement money is an additional punishment, but currently, the efforts to return state assets, especially money that has been corrupted by the perpetrators are done increasingly. These efforts can begin when investigating corruption. In this stage, the Prosecutor can confiscate the assets of the defendant that are suspected to have originated from the proceeds of crime..$^{22}$

Based on data related to the execution of the payment of replacement money in corruption cases such as in Bali High Prosecutor's Office above, it can be seen that there are still arrears of the payment of replacement money from 2012 to 2016. The amount that was successfully executed is not comparable to the amount of losses suffered by the State. From this data, we can also see that the timeframe for billing by the Prosecutor's Office to the convicted person requires a longer period of time that the time limit provided in Article 18 paragraph (2) of Law No. 31 of 1999 in conjunction with Law No. 20 of 2001 which is 1 month after the Verdict enforced.

Based on the interview with Mr. I Wayan Suardi, S.H as the Head of Prosecution for Special Crimes of Bali High Prosecutor's Office, said that if in case of the payment of replacement money the arrears occurred, the settlement steps are as follows:

1. Non-litigation billing to the convicts and their family. After the payment is made, then proof of payment is then given to recorded in administration in the field of civil and state administration, coaching and the field of special criminal offenses

2. Assets Tracing, is a technique used by investigators or forensic auditors by collecting and evaluating evidence of financial and non-financial transactions relating to assets from corruption and or money laundering which is hidden by

${ }^{20}$ Muhammad, Y. (2013). Merampas Aset Koruptor. Solusi Pemberantasan Korupsi di Indonesia. Jakarta. Buku Kompas. h. 57.

${ }^{21}$ Pramudhiyanto, J., Sofyan, A., \& Guntur, M. Upaya Jaksa Pengacara Negara Dalam Mengembalikan Kerugian Keuangan Negara Akibat Tindak Pidana Korupsi.

${ }^{22}$ Rustam, R. (2017). Pelaksanaan Pengembalian Kerugian Keuangan Negara (Asset Recovery) Dalam Tindak Pidana Korupsi (Studi Kasus Kejaksaan Tinggi Sumatera Barat). Jurnal Dimensi, 6(2). 
the perpetrators to be identified, counted, and subsequently in order to freezing their account and confiscate for recovery the State financial losses. If its difficult to resolve, the Prosecutor's Office will cooperate with the Indonesian Attorney General's Asset Recovery Center (PPA).

3. Confiscation of assets of the convicted person. It is possible that after the Verdict to obtain permanent legal force, it is known that there are still assets belonging to a corruption convict that has not seizure (whereas in court the defendant cannot prove that the assets are not obtained by corruption).

4. The imposition of subside criminal sanctions, as determined in Article 18 paragraph (3) that a convict who does not have sufficient assets to pay the replacement money will automatically undergo a prison in accordance with the duration determined in the Verdict. This also applies to the convicts of corruption who have arrears to pay the replacement money.

5. Civil Lawsuit, if the problem cannot solve by non-litigation process, The Prosecutor's Office submit the civil lawsuit against the convict regarding unlawful acts of the unpaid replacement money. Civil lawsuit can be made because of the arrears in the payment of replacement money. As stated in the provisions of Article 3 of Indonesian Civil Code that states "no punishment shall result in civil death or the loss of all civil rights". A replacement money in arrears despite being replaced with a criminal subsidiary as stipulated in Article 18 paragraph (3) of Law No. 31 of 1991 in conjunction with Law No. 20 of 2001 concerning Eradication of Corruption is determined as State receivables. So that in this case civil lawsuit can be done.

6. Put the civil liability on perpetrators of corruption and heirs is expect to return the State financial losses at the same time it can be a shock therapy because if the corruptor dies before he can pay off and return the money to the State, then the settlement can still be prosecuted to the heirs. This is referring into O.C. Kaligis contention regarding the use of civil instruments in recovering State financial losses in the procedure of returning assets to full compliance with the applicable civil law provisions, both material and formal. The relationship between assets and person, whether he is an offender or not, is regulated in material laws into the area of Civil Law. While to return the State financial losses using criminal instruments according to corruption eradication law is carried out through the process of confiscation, seizure and criminal penalties. ${ }^{23}$

In filing a civil lawsuit, the Prosecutor will include a request for a confiscation (consevatoir beslag) on the property belonging to the convicted person. This is in line with the provisions of Article 1131 of Indonesian Civil Code which states "all material debts, both movable and immovable, either present or future, shall be regarded as securities for the debtor's personal agreements". Civil lawsuit related to the effort of returning or pay the replacement money are carried out in accordance with the provisions stipulated in Staatsblad 1922 No. 522 and the law and regulation with applicable Indonesian Civil Procedural Law. In accordance with its function, the Junior

23 Zebua, F. R. P., Jauhari, I., \& Siregar, T. (2008). Tanggungjawab Pelaku Tindak Pidana Korupsi dan Ahli Warisnya Dalam Pembayaran Uang Pengganti Kerugian Keuangan Negara Ditinjau Dari Aspek Hukum Perdata (Studi Kasus Pada Pengadilan Negeri Medan). Jurnal Mercatoria, 1(2), 150-162. DOI: https://doi.org/10.31289/mercatoria.v1i2.635. 
Attorney General for General Crimes cq. The Directorate of Civil Attorney General of The Republic of Indonesia collects, examines control, guides and supervises the implementation of any civil lawsuit, which are related to the payment of the replacement money, then reports the results to the Attorney General of the Republic of Indonesia, up. Junior Attorney General for General Crimes and Special Crimes.

If the convicted person no longer possesses assets to be confiscated and to be auctioned to the State, as evidence by the statement of the related institution such as head of district, the abolition of State receivables must be proposed so that the convicted person must replace it by corporal punishment. This is in accordance with Minister of Finance of Republic Indonesia Regulation No. 31/PMK.07/2005 that based on Indonesia Government Regulation No. 14 of 2005 concerning Procedure of eliminating State/Regional receivables. This was stated in Attorney General's Circular Letter Number: B-779/F/Fjb/ft/10/2005 concerning Arrears of Replacement Money.

That regulation could be misused by the convicted person to escape the responsibility to pay the replacement money with a statement of incapacity from related institution. As we all know that the perpetrators of corruption are people who have a level of intelligence that can deceive law enforcement officers, for example, long before an investigation is conducted, the corruptors have transferred their property to the heirs or other people to eliminating evidence ang make it difficult to prove that he has committed to corruption.

According to the theory of authority as stated by HD van Wijk/Willem Konijnembelt the granting of authority can be through three ways, one of which is giving of authority by attribution. The law attributively provides function and authorities, which are Prosecutor as the investigator and Public Prosecutor as the executor of the Verdict. The functions and authoritative authority of the Prosecutor as the Public Prosecutor is morally and legally obliged to prosecute the accused of corruption with additional criminal charges in the form of returning State financial losses in the form of payment of replacement money as an application of Article 18 paragraph (1) point b of Law No. 31 of 1999 concerning Eradication of Corruption. Implicitly, there is no obligation for the Prosecutor as the Public Prosecutor to include additional criminal charges in the form of replacement money for every corruption defendant.

\section{Conclusion}

There are no complete rules related to execution by Prosecutor in the payment of replacement money. The correlation of laws is not cyclical and has not certainly been established yet. The convict of corruption has a tendency to not pay the replacement money and prefer to have criminal subsidiary punishment, for the reason of the assets has been exhausted, the high amount of replacement money, the assets are in the third parties or the assets has been money laundering.

Legislative is expected to formulate the regulation concerning the procedure for Prosecutor to execute the assets of the corruptor that has been exhausted or in the third party hands to avoid State financial losses. As the executor, special criminal investigator and law enforcer, the Prosecutor expected to function their attributive authority to return the State financial losses optimally from the corruptor by executing the payment of replacement money to maintain a due process of law in combating corruption. 


\section{References}

\section{Books}

Chaerudin, S. A. D., \& Fadillah, S. (2008). Strategi Pencegahan \& Penegakan Hukum Tindak Pidana Korupsi, Bandung: PT. Reflika Aditama.

Hiariej. E. O. S. (2014) Prinsip-Prinsip Hukum Pidana, Jakarta, Cahaya Atma Pustaka.

Jaya, N. S. P. (2008). Beberapa Pemikiran Ke Arah Pengembangan Hukum Pidana. Citra Aditya Bakti.

Muhammad, Y. (2013). Merampas Aset Koruptor. Solusi Pemberantasan Korupsi di Indonesia. Jakarta. Buku Kompas.

Siahaan, N. H. T. (2005). Pencucian Uang Dan Kejahatan Perbankan: (Mengurai UU No. 15 Tahun 2002 Dengan Perubahan UU No. 25 Tahun 2003 Tentang Tindak Pidana Pencucian Uang). Pustaka Sinar Harapan.

Soekanto, S. (1983). Faktor-Faktor Yang Mempengaruhi Penegakan Hukum. Jakarta. Rajawali.

Surachmin \& Cahaya, S. (2011). Strategi \& Teknik Korupsi. Jakarta: Sinar Grafika.

\section{Journal}

Deli, R. R. (2016). Implementasi Perampasan Aset Hasil Tindak Pidana Korupsi Menurut Undang-Undang. Lex Administratum, 4(4).

Kenap, D. (2017). Penyelesaian Uang Pengganti Oleh Ahli Waris Dalam Tindak Pidana Korupsi Berdasarkan Undang-Undang Nomor 31 Tahun 1999 Tentang Pemberantasan Tindak Pidana Korupsi Sebagaimana Telah Diubah Dalam Undang-Undang Nomor 20 Tahun 2001 Tentang Tindak Pidana Korupsi. Lex Administratum, 5(4).

Lukas, A. P. (2010). Efektivitas Pidana Pembayaran Uang Pengganti Dalam Tindak Pidana Korupsi (Studi Putusan Tindak Pidana Korupsi di Pengadilan Negeri Purwokerto). Jurnal Dinamika Hukum,10(2), 81-92. DOI: http://dx.doi.org/10.20884/1.jdh.2010.10.2.142.

Mahmud, A. (2017). Dinamika Pembayaran Uang Pengganti Dalam Tindak Pidana Korupsi. Jurnal Hukum Mimbar Justitia, 3(2), 137-156. DOI: https://doi.org/10.35194/jhmj.v3i2.216.

Pramudhiyanto, J., Sofyan, A., \& Guntur, M. Upaya Jaksa Pengacara Negara Dalam Mengembalikan Kerugian Keuangan Negara Akibat Tindak Pidana Korupsi.

Prakarsa, A., \& Yulia, R. (2017). Model Pengembalian Aset (Asset Recovery) Sebagai Alternatif Memulihkan Kerugian Negara Dalam Perkara Tindak Pidana Korupsi. Jurnal Hukum PRIORIS, 6(1).

Prasetyo, D. R. (2016). Penyitaan Dan Perampasan Aset Hasil Korupsi Sebagai Upaya Pemiskinan Koruptor. DiH: Jurnal Ilmu Hukum, 12(24), 149-163. DOI: https://doi.org/10.30996/dih.v12i24.2243.

Rewah, C. D. (2019). Pengembalian Kerugian Negara Akibat Tindak Pidana Korupsi Berdasarkan Undang-Undang Nomor 20 Tahun 2001. Lex Crimen, 8(7).

Rustam, R. (2017). Pelaksanaan Pengembalian Kerugian Keuangan Negara (Asset Recovery) Dalam Tindak Pidana Korupsi (Studi Kasus Kejaksaan Tinggi Sumatera Barat). Jurnal Dimensi, 6(2).

Sinulingga, E. E. (2017). Pengembalian Aset Hasil Tindak Pidana Korupsi Melalui Mekanisme Gugatan Perdata. Lex Administratum, 5(4). 
Syarifuddin, M. S. A. (2019). Wewenang Jaksa Pengacara Negara Dalam Pengembalian Uang Pengganti Perkara Tindak Pidana Korupsi. Simbur Cahaya, 25(2), 207-223. DOI: http://dx.doi.org/10.28946/sc.v25i2.331.

Syaifulloh, A. (2019). Peran Kejaksaan Dalam Pengembalian Kerugian Keuangan Negara Pada Perkara Tindak Pidana Korupsi. Indonesian Journal of Criminal Law, 1(1), 47-64. DOI: https://doi.org/10.31960/ijocl.v1i1.147.

Zebua, F. R. P., Jauhari, I., \& Siregar, T. (2008). Tanggungjawab Pelaku Tindak Pidana Korupsi dan Ahli Warisnya Dalam Pembayaran Uang Pengganti Kerugian Keuangan Negara Ditinjau Dari Aspek Hukum Perdata (Studi Kasus Pada Pengadilan Negeri Medan). Jurnal Mercatoria, 1(2), 150-162. DOI: https://doi.org/10.31289/mercatoria.v1i2.635. 